\title{
The effect of purchasing strategy on supply management performance through supplier integration and supplier relationship management
}

\author{
N. Wasthy, Z.J.H. Tarigan \& H. Siagian \\ Faculty of Business and Economics, Petra Christian University, Surabaya, Indonesia
}

\begin{abstract}
The purchasing strategy is based on building mutual relationships with suppliers. This study examines the effect of purchasing strategy on supply management performance through supplier integration and supplier relationship management. The respondents are employees involved with the suppliers of the company daily. The findings demonstrate that purchasing strategy affects supplier relationship management and improves supplier integration and supply management performance. Consequently, supplier relationship management affects two aspects, namely supplier integration and supply management performance. The latter is also significantly affected by the former. Lastly, the finding shows that supplier relationship management and supplier integration mediate the influence of purchasing strategy on supply management performance. In conclusion, purchasing strategy improves the supply management performance both directly and indirectly.
\end{abstract}

\section{INTRODUCTION}

Companies need to capitalize on the benefits of working with suppliers by practicing a supply management approach. Particularly during the current pandemic era, delivery sustainability has become a critical issue due to the supply chain disruption. Companies are required to use more resources to ensure the supply of material runs effectively. Hence, cooperation with the supplier becomes more vital to provide quality products at competitive prices. Tarigan et al. (2019b) stated that organizations should focus on their core business and allow suppliers, as partners, to provide quality materials at a low cost rather than to produce their source of supply. Organizations need to manage the supply network to optimize overall company performance and align the overall demand channel to ensure efficient delivery.

Companies' relationship with suppliers is the strongest cooperation in the value chain or supply chain (Tarigan et al. 2019a). Companies' purchasing strategy impacts the sustainability of processes on an ongoing basis. Hence, companies' purchasing strategy must maintain effective communication with the material supplier. According to Al-Shboul et al. (2018), the integration built by cooperation with external parties will provide companies adequate flexibility. Tarigan et al. (2019a) state that purchasing strategy can positively impact process integration and improve both parties' performance. Companies determine the purchasing strategy by taking into account the strength of the relationship with their suppliers. Furthermore, companies' ability to coordinate with suppliers or material providers can help companies to increase their competitiveness and profit in the long-term through operational cost reduction, quality improvement, and accurate delivery (Sarang et al. 2018).

Supplier integration can provide a better and more sustainable relationship between companies and their suppliers as trust between the two parties leads to an efficient and effective material flow (Zhang \& Huo 2013). Kumar \& Rahman (2106) state that integration with suppliers enables companies to select the best suppliers, develop new products, and improve firm performance. Moreover, suppliers' involvement in the company's product design process can improve supplier 
performance and eventually improves company performance (Sánchez-Rodríguez 2009). Semuel et al. (2018) suggest excellent cooperation through involving suppliers in its internal processes and sharing knowledge can enhance company performance.

This study investigates one of the largest mining companies in the nickel mining industry, located in Sorowako, South Sulawesi, Indonesia. This company cooperates with many suppliers to support its operation. The price of nickel significantly affects the mining company's financial condition and operation results. Unfortunately, nickel prices fluctuate and are strongly influenced by global demand and supply as well as nickel substituted product availability and prices. About $65 \%$ of company production cost is determined by the supply of goods and services cost (fuel, supporting materials, and service costs). Thus, supply management function and role are crucial to improving business margins through efficiency and cost optimization to achieve a long-term sustainable growth strategy.

This study explores some of the antecedents of supply management performance and understands how it affects supply management performance. Understanding these antecedents is expected to improve existing management performance to achieve corporate strategy success. This study has two primary objectives: first, to measure the purchasing strategy's impact on supplier integration, supplier relationship management, and supply management performance; second, to measure supplier integration's impact on supplier relationship management and supply management performance.

\section{RELATIONSHIP BETWEEN RESEARCH CONCEPTS}

The primary purchasing concerns with the supply market environment and activity are securing the materials, components, and equipment by selecting capable suppliers. Research conducted by Tarigan et al. (2020) establishes indicators for purchasing strategies in manufacturing companies, namely estimating potential suppliers, developing suppliers in companies, making contracts with company suppliers, making long-term plans, and evaluating suppliers' ongoing basis. Companies can build relationships with their suppliers who are fully committed to providing value for companies to produce products at relatively lower costs (Yoon \& Moon 2019). Hence, based on the theory above, the first hypothesis as follows:

\section{$H_{1}$ : Purchasing strategy affects supplier relationship management.}

Broad supplier integration is recommended to ensure accurate and quick delivery of material, parts, or modules from suppliers. Since new critical technologies or knowledge of components or materials for specific product types are often controlled by suppliers, integration offers a more efficient way of accessing this knowledge than traditional market relationships (Shou et al. 2017). Also, integration positively affects the enterprise and various functional performances, including production costs, product quality, on-time delivery, delivery times, inventory turnover times, inventory turnover rates, new product introductions, adjustment performance, logistics service performance, customer satisfaction, sales growth, sales returns, and ROI (Ellegaard \& Koch 2014). Hence, based on the description above, the second hypothesis is as follows:

\section{$\mathrm{H}_{2}$ : Purchasing strategy affects supplier integration.}

Evaluation of suppliers through field visits and the use of a supplier reward and reward system improves supplier performance. Buyer involvement in the supplier's new product design process results in better performance for both suppliers and buyers. The development of suppliers in improving supply management performance, in turn, will result in improvements in the purchasing performance of the company (Sánchez-Rodríguez 2009). Based on the theory, the third hypothesis is as follows:

\section{$\mathrm{H}_{3}$ : Purchasing strategy affects supply management performance.}


Supplier relationship management is characterized by structural interdependence and asymmetrical distribution of resources, which creates dependency among members. The management reflects bargaining power and the importance of the relationship between partners. Trust and dependence exist simultaneously in supplier relationship management. The integration of influence through understanding the independent and shared effects of dependence as well as trust on supplier relationship management can help practitioners build and manage social ties efficiently and effectively. Several empirical studies (see, for example, Zhang \& Huo 2013) have confirmed the impact of dependence and trust in supplier integration. The fourth hypothesis is formulated as follows:

\section{$H_{4}$ : Supplier relationship management affects supplier integration.}

Suppliers are involved in identifying buyer expectations. Companies' relationship with suppliers is valuable and useful as suppliers become tools that help companies achieve their goals (Tarigan et al. 2019b). Meeting buyer expectations, which are quality, quantity, delivery, service, and price, can help companies improve overall quality to reduce costs and competition (Al-Shboul et al. 2017). Robust cooperation between companies and their suppliers, such as involving suppliers in internal processes and knowledge sharing, can improve construction companies' performance (Samuel et al. 2018). This argument postulates the fifth hypothesis below:

\section{$H_{5}$ : Supplier relationship management affects supply management performance.}

Supplier integration and coordination are often seen as drivers for better performance as alliance mechanisms can generate revenue for both parties (González-Benito et al. 2016). Supplier integration, which positions the supplier as a manufacturer's long-term strategic collaborator, can improve operational performance. Effective supplier management can reduce variance in incoming materials and parts and ensure that suppliers meet specifications and quality standards. This management reduces process variability and can positively affect product delivery times, reliability, quality, and potential defects. These benefits can only be obtained if suppliers are involved early in the process (He et al. 2014). This description determines the last hypothesis as follows:

$H_{6}$ : Supplier integration affects supply management performance.

\section{METHODS}

This study's population is a supplier company that cooperates with a Nickel mining company in South Sulawesi, Indonesia. This study's unit analysis is suppliers cooperating with one mining company in Sorowako, South Sulawesi, Indonesia. The respondents are 37 full-time employees of the mining company whose main jobs are directly related to suppliers (employees engaged in the inbound logistic department).

The research framework and the relationship between concepts are demonstrated in Figure 1.

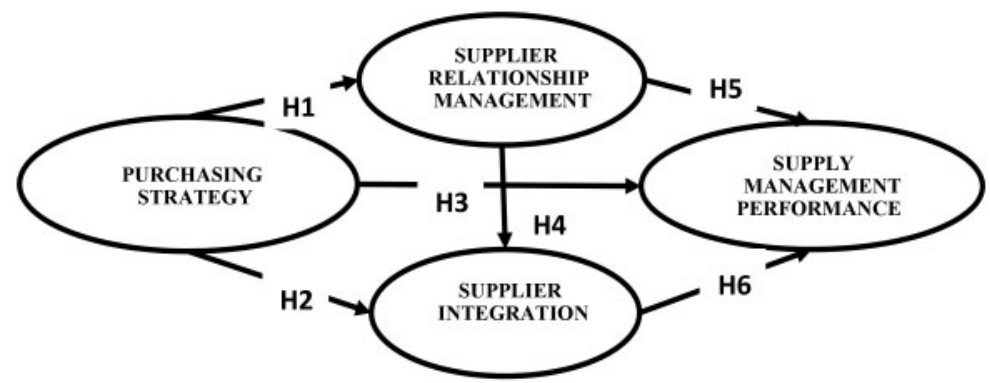

Figure 1. Research framework and concepts relationship. 


\section{FINDINGS AND DISCUSSION}

Of the total employees, $24 \%$ have been working for 1 to 3 years, $14 \%$ for 3 to 5 years, and $62 \%$ for more than five years. Meanwhile, based on the jobs of the respondents, 22 employees $(59 \%)$ are from the supply management department, $6(16 \%)$ from the operational procurement department, and 9 (25\%) are from procurement support, projects, export-imports, goods spots, logistics, shipping, and material management.

Purchasing strategy influences the supplier relationship management relationship $\left(\mathrm{H}_{1}\right)$. This result proves that purchasing strategy influences the establishment of supplier relationship management. This finding indicates that the company's ability to build communication and negotiation with suppliers effectively increases company suppliers' alignment and helps the company meet its needs.

The findings also prove the effect of purchasing strategy on supplier integration $\left(\mathrm{H}_{2}\right)$. The result suggests that to build effective communication and negotiation with suppliers, the company should involve suppliers in the product development process. Planning is an integrated process as it controls the raw materials needed for production. This study's findings are in line with several researchers that suggest the need of suppliers to involve in the product development process to maintain effective communication and negotiation with suppliers. The results also indicate the effect of purchasing strategy on improving supply management performance $\left(\mathrm{H}_{3}\right)$. This finding proves that the company's ability to establish effective communication and negotiation with suppliers is essential in reducing inventory and increasing internal efficiency. This finding supported previous researchers who found that purchasing strategy improves the supply management performance.

Furthermore, the results also show that supplier relationship management practices enhance supplier integration $\left(\mathrm{H}_{4}\right)$. This finding indicates that the company can build alignment with suppliers and meet their needs. This process requires suppliers to involve in product development, especially when company planning is integrated with the supplier. This study supports past research which found that supplier relationship management practices affect supplier integration. The result shows that the supplier relationship management improves supply management performance $\left(\mathrm{H}_{5}\right)$. This value indicates that the company's ability to build alignment with suppliers is valuable and useful since it enables suppliers to meet their needs to reduce inventory and improve internal efficiency. This study supports the research that supply management performance improves when supplier relationship management runs well.

Lastly, this study found that supplier integration affects supply management performance. This finding indicates that the company's ability to develop products and mechanisms to reduce inventory and increase internal efficiency can reduce transaction costs, generating relational resources and capabilities to maintain a competitive advantage. This study supports the research that examined the effect of supplier integration on management performance. As this research model involves the mediating variable, supplier integration, and supplier relationship management, the result of the analysis regarding the mediating role is interpreted as follows. The mediating role's result can be analyzed by firstly looking at the result of those hypotheses. The mediating role is present when each relationship between the two variables is significant or supported. As those hypotheses are significant, the mediating role of supplier integration and supplier relationship management exists. Hence, purchasing strategy improve supply management performance both directly and directly. This finding reveals that the purchasing strategy establishment is essential in improving supply management performance by implementing supplier integration and supplier relationship management.

\section{CONCLUSION}

This research primarily examines the effect of purchasing strategy on supply management performance through supplier integration and supplier relationship management. This research concludes that (1) the purchasing strategy has a significant effect on supplier relationship management, (2) 
the purchasing strategy has a significant effect on supplier integration and supply management performance, (3) supplier relationship management has a significant effect on supplier integration and supply management performance, and (4) supplier integration has a significant effect on supply management performance. Another important finding is that supplier integration and supplier relationship management mediate purchasing strategy on supply management performance. Purchasing strategy improves the supply management performance both directly and indirectly. Hence, purchasing strategy is crucial in improving supply management performance through supplier integration and supplier relationship management. This research contributes to the ongoing research in supply chain management theory by providing essential insight for the practitioner in improving the supply management performance.

\section{REFERENCES}

Al-Shboul, M.A.R., Barber, K.D., Garza-Reyes, J.A., Kumar, V., \& Abdi, M.R. (2017). The effect of supply chain management practices on supply chain and manufacturing firms' performance. Journal of Manufacturing Technology Management, 28(5), 577-609. doi:10.1108/jmtm-11-2016-0154.

Ellegaard, C. and Koch, C. (2014), A model of functional integration and conflict: The case of purchasingproduction in a construction company, International Journal of Operations \& Production Management, 34(3), 325-346. https://doi.org/10.1108/IJOPM-03-2012-0108.

Fynes, B. and Voss, C. (2002), The moderating effect of buyersupplier relationships on quality practices and performance, International Journal of Operations \& Production Management, 22(6), 589-613. https://doi.org/10.1108/01443570210427640.

He, Y., Keung Lai, K., Sun, H., \& Chen, Y. (2014). The impact of supplier integration on customer integration and new product performance: The mediating role of manufacturing flexibility under trust theory, International Journal of Production Economics, 147, 260-270. doi:10.1016/j.ijpe.2013.04.044.

Kumar, D., and Rahman, Z. (2016). Buyer supplier relationship and supply chain sustainability: empirical study of Indian automobile industry, Journal of Cleaner Production, 131, 836-848, https://doi.org/ 10.1016/j.jclepro.2016.04.007.

SánchezRodríguez, C. (2009), Effect of strategic purchasing on supplier development and performance: a structural model, Journal of Business \& Industrial Marketing, 24(3/4), 161-172. https://doi.org/10.1108/ 08858620910939714.

Sarang, J., Pankaj, S., Rajendra, C., and Joshi. P.P., (2018). Strategies for buyer supplier relationship improvement: scale development and validation, Procedia Manufacturing 20, 470-476.

Semuel, H., Siagian, H., Arnius, R. (2018). The effects of strategic purchasing on organization performance through negotiation strategy and buyer-supplier relationship, International Journal of Business and Society, 19 (2), 323-334.

Tarigan, Z.J.H., Siagian, H., Basana, R.S., and Jie, F., (2019a). Effect of key user empowerment, purchasing strategy, process integration, production system to operational performance, E3S Web of Conferences, 130, 01042, https://doi.org/10.1051/e3sconf/201913001042.

Tarigan, Z.J.H., Siagian, H. and Bua, R.R. (2019b). The impact of information system implementation to the integrated system for increasing the supply chain performance of manufacturing companies, IOP Conference Seri: Material Science and Engineering, 473, 012050, doi:10.1088/1757-899X/473/1/012050.

Tarigan, Z.J.H., Siagian, H., and Jie, F. (2020). The role of top management commitment to enhancing the competitive advantage through ERP integration and purchasing strategy. International Journal of Enterprise Information Systems, 16(1), 53-68.

Yoon, J., and Moon, J. (2019). The moderating effect of buyer purchasing strategy on the relationship between supplier transaction-specific investment and supplier firm performance, Journal of Business Research, 99, 516-523.

Zhang, M. and Huo, B. (2013). The impact of dependence and trust on supply chain integration, International Journal of Physical Distribution \& Logistics Management, 43(7), 544-563. https://doi.org/10.1108/ IJPDLM-10-2011-0171. 